\title{
EFFECT OF COMPENSATION ON EMPLOYEE MOTIVATION (Study on BPRS in Sukabumi Regency/City)
}

\author{
Tetty Sufianty Zafar ${ }^{1}$, Usep Dayat ${ }^{2}$ \\ ${ }^{1}$ Universitas Ibn Khaldun UIKA Bogor, ${ }^{2}$ Universitas Singaperbangsa Karawang \\ Email : ${ }^{1}$ tetty.sufiantyzafar@uika-bogor.ac.id, ${ }^{2}$ fisip@unsika.ac.id
}

\begin{abstract}
In general, every employee who works at a company is to make a living to meet their needs. With a variety of abilities, knowledge, and skills that employees have to work. Because employees expect a reward or repayment. In a company the compensation or remuneration is called compensation. The amount of compensation that the company has given to employees has been determined and known in advance, so that employees are certain of the compensation they will receive. This compensation will be used by employees and their families to meet their needs. The amount of compensation reflects the status, recognition and level of fulfillment of the needs enjoyed by the employee along with his discharge. If the compensation received by the employee means the higher the position, the better the status and the fulfillment of the needs that he enjoys more and more.

The method used in this research is descriptive and verification analysis, which examines the status of a group of people, an object, a set of conditions, a system of thought, or a class of events in the present, with the aim to make a systematic, factual description, picture or painting. and be accurate regarding the facts, traits and relationships between the phenomena investigated. As well as testing the relationship of variables from proposed hypotheses accompanied by empirical data.

Based on research results the effect of compensation on Work motivation is $70.06 \%$ or it can be said also, that the variance that occurs in the Work Motivation variable (Y) 70.06\% is determined by the variance that occurs in the Compensation variable $(X)$. The remaining $29.94 \%$ is determined by other factors outside the study, such as motivation, wages, employee placement, and others.
\end{abstract}

Keywords: Compensation and Motivation

\begin{abstract}
Abstrak
Pada umumnya setiap karyawan yang bekerja pada suatu perusahaan adalah untuk mencari nafkah guna memenuhi kebutuhannya. Dengan berbagai kemampuan, pengetahuan, serta keterampilan yang karyawan miliki untuk bekerja. Karena karyawan mengharapkan suatu imbalan atau balas jasa. Dalam suatu perusahaan imbalan atau balas jasa itu disebut dengan kompensasi. Besarnya kompensasi yang tellah diberikan perusahaan kepada karyawan sudah ditentukan dan diketahui sebelumnya, sehingga karyawan secara pasti mengetahui kompensasi yang akan diterimanya. Dengan kompensasi inilah yang akan dipergunakan karyawan beserta keluarganya untuk memenuhi kebutuhan-kebutuhannya. Besarnya kompensasi mencerminkan status, pengakuan dan tingkat pemenuhan kebutuhan yang dinikmati oleh karyawan bersama keluarnya. Jika kompensasi yang diterima karyawan semakin besar berarti jabatannya semakin tinggi, statusnya semakin baik dan pemenuhan kebutuhan yang dinikmatinya semakin banyak.

Metode yang digunakan dalam penelitian ini adalah analisis deskriptif dan verifikatif, yang meneliti status sekelompok manusia, suatu objek, suatu set kondisi, suatu sistem pemikiran, ataupun suatu kelas peristiwa pada masa sekarang, dengan tujuan untuk membuat deskripsi, gambaran atau lukisan secara
\end{abstract}


sistematis, factual dan akurat mengenai fakta-fakta, sifat-sifat serta hubungan antarfenomena yang diselidiki. Serta menguji hubungan variabel dari hipotesis-hipotesis yang diajukan disertai data empiris.

Berdasarkan hasil penelitian pengaruh kompensasi terhadap motivasi Kerja adalah sebesar 70,06\% atau dapat dikatakan pula, bahwa varians yang terjadi pada variabel Motivasi Kerja (Y) 70,06 \% ditentukan oleh varians yang terjadi pada variabel Kompensasi (X). Sisanya sebesar 29,94\% ditentukan oleh faktorfaktor lain diluar penelitian, seperti motivasi, upah, penempatan pegawai, dan lain-lain.

Kata kunci : Kompensasi dan Motivasi

\section{PENDAHULUAN}

Persaingan dunia industri di perusahaan saat ini semakin ketat. Dimana masing-masing perusahaan tersebut saling bersaing, dalam meningkatkan mutuproduk yang dihasilkan, untuk menarik minat konsumen supaya membeli produk yang ditawarkan oleh perusahaan. Untuk dapat bersaing di dalam industri tersebut maka dibutuhkan sumber daya manusia yang berkualitas. Maka perusahaan harus mampu mengelola sumber daya manusia dengan baik untuk mencapai tujuan yang telah direncanakan.

Bagi perusahaan, dalam mengelola sumber daya manusia bukanlah ha yang mudah. Mengelola sumber daya manusia berarti merencanakan, mengorganisasikan, mengarahkan dan mengendalikan aktivitas karyawan untuk mencapai tujuan yang telah direncanakan perusahaan. Sulitnya mengelola karyawan dikarenakan karyawan merupakan manusia yang memiliki sifat dan perilaku serta kebutuhan yang berbeda-beda.

Pada umumnya setiap karyawan yang bekerja pada suatu perusahaan adalah untuk mencari nafkah guna memenuhi kebutuhannya. Dengan berbagai kemampuan, pengetahuan, serta keterampilan yang karyawan miliki untuk bekerja. Karena karyawan mengharapkan suatu imbalan atau balas jasa. Dalam suatu perusahaan imbalan atau balas jasa itu disebut dengan kompensasi.

Besarnya kompensasi yang tellah diberikan perusahaan kepada karyawan sudah ditentukan dan diketahui sebelumnya, sehingga karyawan secara pasti mengetahui kompensasi yang akan diterimanya. Dengan kompensasi inilah yang akan dipergunakan karyawan beserta keluarganya untuk memenuhi kebutuhan-kebutuhannya. Besarnya kompensasi mencerminkan status, pengakuan dan tingkat pemenuhan kebutuhan yang dinikmati oleh karyawan bersama keluarnya. Jika kompensasi yang diterima karyawan semakin besar berarti jabatannya semakin tinggi, statusnya semakin baik dan pemenuhan kebutuhan yang dinikmatinya semakin banyak.

Kompensasi merupakan pengeluaran dan biaya bagi perusahaan. Perusahaan mengaharapkan agar kompensasi yang dibayarkan memperoleh imbalan prestasi yang lebih besar dari karyawannya. Oleh karena itu perusahaan harus mampu mengelola kompensasi dengan baik sehingga bisa memenuhi persyaratan adil dan layak. Dengan pelaksanaan pemberian kompensasi yang adil dan layak, karyawan akan senang dalam bekerja dan akan termotivasi untuk bekerja lebih baik, sehingga tujuan perusahaan tercapai.

Adapun tujuan dasar dari pemberian kompensasi menurut Henry Simamora (2009:459) adalah untuk memikat, menahan dan memotivasi para karyawan. Jadi apabila suatu perusahaan tidak mampu mengembangkan dan menerapkan kompensasi yang adil dan layak, maka kemungkinan perusahaan akan kehilangan tenaga kerja terampil dan berkemampuan tinggi. Selain itu motivasi karyawan pun akan menurun karena kebutuhan karyawan belum terpenuhi. Turunnya motivasi kerja karyawan akan merugikan perusahaan. Karena bagi karyawan bekerja pada suatu perushaan merupakan suatu cara mencari nafkah guna memenuhi kebutuhan hidupnya dengan mengharapkan imbalan yang sesuai dengan tingkat kemampuan, pengetahuan, dan keterampilan yang diilikinya.

Apabila di dalam perusahaan timbul ketidak adilan maka karyawan belum merasakan kepuasan dalam pemberian kompensasi yang diberikan oleh perusahaan, sehingga penulis menduga adanya pengaruh tentang ketidakpuasan pemberian kompensasi terhadap motivasi kerja karyawan

Dalam penelitian ini dilakukan survey pendahuluan, kepada 10 responden mengenai kompensasi sebagai berikut : 
Tabel 1. Data Survey Pendahuluan Penelitian

\begin{tabular}{|c|l|c|c|c|c|}
\hline \multicolumn{5}{|c|}{ DATA KUESIONER PENDAHULUAN } \\
\cline { 3 - 6 } NO PERTANYAAN & \multicolumn{1}{|c|}{ YA } & \multicolumn{2}{c|}{ TIDAK } \\
\hline & \multicolumn{1}{|c|}{$\begin{array}{l}\text { Gaji yang anda terima cukup untuk kebutuhan } \\
\text { sehari-hari }\end{array}$} & 5 & $50 \%$ & 5 & $50 \%$ \\
\hline 2 & Gaji yang diberikan perusahaan layak/wajar & 3 & $30 \%$ & 7 & $70 \%$ \\
\hline 3 & $\begin{array}{l}\text { Insentif yang perusahaan berikan layak/wajar dan } \\
\text { adil }\end{array}$ & 4 & $40 \%$ & 6 & $60 \%$ \\
\hline 4 & Bonus yang anda terima memuaskan & 5 & $50 \%$ & 5 & $50 \%$ \\
\hline & \multicolumn{1}{|c|}{ Jumlah prosentase rata2 respon } & 17 & $42,5 \%$ & 23 & $57,5 \%$ \\
\hline
\end{tabular}

Sumber: olahan penulis dari survey ke perusahaan (28 Maret 2016)

Dari penelitian pendahuluan di atas dapat dilihat bahwa terdapat ketidakpuasan karyawan terhadap kompensasi yang diberikan oleh perusahaan, dengan presentase lebih banyak yang menjawab tidak sebesar $(57,5 \%)$ daripada yang menjawab Ya sebesar $(42,5 \%)$ hal ini akan berdampak kepada motivasi karyawan yang rendah.

\section{KERANGKA TEORITIS \& HIPOTESIS Motivasi Kerja}

Pengerian motivasi menurut Edwin B Flippo (Malayu S.P Hasibuan, 2007: 143) Motivasi adalah:"Suatu keahlian dalam mengarahkan pegawai dan organisasi agar mau bekerja secara berhasil, sehinga tercapai keinginan para pegawai sekaligus tercapainya tujuan organisasi".

MalayuS.P Hasibuan (2007:143) menyatakan bahwa:

Motivasi adalah pemberian daya penggerak yang menciptakan kegairahan kerja seseorang agar mereka mau bekerja sama, bekerja efektif dan terintegrasidengan segala daya upayanya untuk mencapai kepuasan.

Sedangkan Herman Sofyandi berpendapat (2007:174) bahwa: "Motivasi merupakan sesuatu kekuatan dorongan atau kemampuan gerak yang melekat pada setiap individu, hal mana ini menyebabkan munculnya perilaku manusia".

Adapun pengertian motivasi kerja menurut Ernest J. Mc Cormick yang dikutip oleh Mangkunegara (2007:94) adalah sebagai berikut: "Motivasi kerja didefiisikan sebagai kondisi yang berpengaruh membangkitkan, mengarahkan dan memelihara perilaku yang berhubungan dengan lingkungan kerja".
Dari beberapa penggertian diatas disimpulkan bahwa motivasi merupakan suatu kekuatan dorongan atau kemampuan gerak yang ada pada diri seseorang yang mendorong dan mengarahan orang tersebut untuk berperilaku atauberbuat sesuatu untuk mencapai tujuannya secara pribadi dan ttujuan perusahaan.

\section{Tujuan Motivasi Kerja}

Tujuan motivasi menurut Hasibuan (2007:146) adalah sebagai berikut:

a. Meningkatkan moral dan kepuasan kerja aryawan

b. Meningkatkan produktivitas kerja karyawan

c. Mempertahankan kestabilan karyawan perusahan

d. Meningkatkan kedisiplinan karyawan

e. Mengefektifkan pengadaan karyawan

f. Menciptakan suasana dan hubungan kerja yang baik

g. Meningkatkan loyalitas, kreativitas, dan partisipasi karyawan

h. Meningkatan tingkat kesejahteraan karyawan

i. Mempertinggi rasa tanggung jawab karyawan terhadap tugas-tugasnya

j. Meningkatkan efesiensi penggunaan alat-alat dan bahan

\section{Asas-Asas Motivasi}

Asas-asas motivasi menurut Hasibuan (2007:146-147) terdiri atas:

a. Asas Mengikutsertakan

Asas mengikutsertakan maksudnya mengajak bawahan untuk ikut berpartisipasi dan memberikan kesempatan kepada mereka untuk 
mengajukan ide-ide, rekomendasi dalam proses pengambilan keputusan. Dengan cara ini bawahan merasa ikutbertanggung jawab atas tercapainya perusahaan, sehingga moral dan gairah kerjanya akan meningkat.

b. Asas Komunikasi

Asas Komuniasi maksudnya menginformasikan secara jelas tentang tujuan yang ingin dicapai, cara mengerjakannya, dan kendala yang dihadapi. Dengan asas komunikasi, motivasi kerja bawahan akan meningkat. Sebab semakin banyak seseorang mengetahua suatu soal semakin besar pula minat dan perhatiannya hal tersebut.

c. Asas Pengakuan

Asas pengakuan maksudnya memberikan penghargaan dan pengakuan yang tepat serta wajar kepada bawahan atas prestasi kerja yang dicapainya. Bawahan akan bekerja keras dan semakin rajin, jika mereka terus-menerus mendapat pengakuan dan kepuasan dari usahausahanya. Dalam memberikan pengakuan atau pujian kepada bawahan hendaknya dijelaskan bahwa dia patut menerima penghargaan itu, karena prestasii kerja atau jasa-jasa yang diberikannya. Pengakuan dan pujian harus diberikan dengan ikhlas dihadapan umum supaya nilai pengauan atau pujian itu semakin besar.

d. Asas Wewenang yang didelegasikan

Yang dimaksud asas wewenang yang didelegasikan adalah mendeleasikan sebagian wewenang serta kebebasan karyawan mengambil keputusan dan berkreativitas dan melaksanakan tugas-tugas atasan atau manajer. Dalam pendelegasian ini, manajer harus meyakinkan bawahan bahwa karyawan mampu dan dipercaya dapat menyelesaikan tugas-tugas itu dengan baik.

e. Asas Perhatian Timbal Balik

Asas perhatian timbal balik adalah motivasi bawahan dengan mengemukakan keinginan atau harapan perusahaan disamping berusaha memenuhi kebutuhan-kebutuhan yang diharapkan bawahan dari perusahaan. Misalnya minta supayakaryawan meningkatkan prestasi kerjanya sehigga perusahaan memperoleh laba yang lebih banyak. Apabila laba semakin banyak, balas jasa merekan akan dinaikkan. Jadi ada perhatian timbal balik untuk memnuhi keingian semua pihak. Dengan asas motivasi ini diharapkan prestasi kerja karyawan akan meningkat.

\section{Teori Motivasi Kerja}

a. Teori Hierarki Kebutuhan dari Maslow:

Abraham Maslow mengemukakan teori hierarki kebutuhan (A.A Anwar Prabu Mangkunegara, 2007:95) yaitu:

1. Kebutuhan Fisiologis

Yaitu kebutuhan untuk makan, minum, perlindungan fisik, bernaas, seksual. Kebutuhan ini merupakan kebutuhan tingkat terendah atau disebut pula sebagai kebutuha paling dasar.

2. Kebutuhan rasa aman

Yaitu kebutuhan akan perlindungan dari ancaman, bahaya, pertentangan dan lingkunagn hidup.

3. Yaitu kebutuhan untuk diterima oleh kelompok, berafiliasi, berinteraksi dan kebutuhan mencintai dan dicintai.

4. Kebutuhan akan harga diri

Yaitu kebutuhan untuk dihormati, dan dihargai oleh orang lain.

5. Kebutuhan untuk mengatualisasikan diri

Yaitu kebutuhan untuk menggunakan kemampuan, skill, dan potensi.

b. Teori motivasi dari Mc Clelland (A.A Anwar Prabu Mangkunegara, 2007:97)

Dalam teorinya David Mc Clelland mengemukakan ada 3 (tiga) macam kebutuhan manusia, yaitu sebagai berikut :

1. Kebutuhan untuk berprestasi (Need For Achievment)

Yaitu kebutuhan untuk berprestasi yang merupakan refleksi dari dorongan akan ditanggung jawab untuk memecahkan masalah. Seorang karyawan yang mempunyai kebutuhan akan prestasi tinggi cenderung untuk berani. Kebutuhan untuk berprestasi adalah kebutuhan untuk melakukan pekerjaan lebih aik dari sebelumnya, selalu berkeinginan mencapai prestasi yang lebih tinggi.

2. Kebutuhan untuk berafiliasi (NeedFor Affilion) Yaitu kebutuhan untuk berafiliasi yang merupakan dorongan untuk berinteraksi dengan orang lain, berada bersama orang lain, tidak mau melakukan sesuatu yang merugikan orang lain.

3. Kebutuhan untuk kekuasaan (Need For Power) 
Yaitu kebutuhan untuk kekuasaan yang merupakan refleksi dari dorongan untuk mencapai otoritas untuk memiliki pengaruh terhadap orang lain.

c. Teori ERG (Existence, Relatedness, Growth) dari Alderfer (A.A Anwar Prabu Mangkunegara, 2007:98) Teori ERG merupakan refleksi dari nama tiga dasar kebutuhan yaitu:

1. Existence needs

Yaitu kebutuhan ini berhubungan dengan fisik dari existensi karyawan, seperti makan, minum, pakaian, bernafas, gaji, keamanan kondisi kerja, Fringe benefits.

\section{Relatednees needs}

Yaitu kebutuhan interpersonal, yaitu kepuasan dalam berinteraksi dalam lingkungan kerja.

3. Growth needs

Yaitu kebutuhan untuk mengembangkan dan meningkatkan pribadi. Hal ini berhubungan dengan kemampuan dan kecakapan karyawan.

\section{Kompensasi}

Pengertian Kompensasi menurut Wather dan Davis yang dikutip oleh Malayu S.P.Hasibuan (2007 : 19) mengemukakan : "Kompensasi adalah apa yang seseorang pekerja terima sebagai balasan dari pekerjaan yang diberikannya, baik upah perjam ataupun gaji periodik didesain dan dikelola oleh bagian personalia.

Pendapat lain dikemukakan oleh Sikula yang dikutip Herman Sofyandi (2008:161-162), menyatakan :"Kompensasi adalah segala sesuatu yang dianggap sebagai suatu balas jasa atau ekuivalen".

Sedangkan Hasibuan berpendapat (2007:118), bahwa :"Kompensasi adalah semua pendapatan yang berbentuk uang, barang langsung atau tidak langsung yang diterima karyawan sebagai imbalan atau jasa yang diberikan kepada perusahaan”.

\section{Tujuan Kompensasi}

Henry Simamora (2009:459), berpendapat bahwa tujuan dasar pemberian kompensasi adalah untuk memikat, menahan dan memotivasi karyawan.

Tujuan kompensasi menurut Malayu S.P. Hasibuan (2007 : 121) adalah : "Sebagai ikatan kerjasama, kepuasan kerja, pengadaan efektif, motivasi, stabilitas karyawan, disiplin, pengaruh serikat buruh, pengaruh pemerintah".
Adapun tujuan pemberian kompensasi menurut Herman Sofyandi (2008, 161 - 162), adalah :

1. Untuk menjalin ikatan kerjasama antara perusahaan dengan karyawan, artinya bahwa dengan terkalinnya kerjasama secara formal akan terbentuk komitmen yang jelas mengenai hak dan kewajiban yang harus dipikul masingmasing.

2. Memberikan kepuasan kepada karyawan, artinya bahwa melalui kepuasam yang dirasakan para karyawan, maka karyawan akan memberikan prestasinya yang baik.

3. Untuk memotivasi karyawan dalam bekerja, artinya agar karyawan bersemangat dalam bekerja dalam rangka memenuhi kebutuhannya.

4. Untuk mencapai disiplin kerja bagi karyawan.

Dari beberapa pendapat diatas tentang tujuan pemberian kompensasi, dapat diambil kesimpulan bahwa tujuan dalam pemberian kompensasi dalam suatu organisasi atau perusahaan adalah untuk menarik dan mempertahankan, serta memotivasi kerja karyawan.

\section{Asas-Asas Kompensasi}

Program Kompensasi (balas jasa) harus ditetapkan atas adil dan layak serta memperhatikan undang-undang perburuhan yang berlaku, prinsip adil dan layak harus mendapat perhatian dengan sebaik-baiknya supaya kompensasi (balas jasa) yang akan diberikan bias memotivasi dan memberikan kepuasan kerja karyawan.

Adapun asas-asas pemebrian kompensasi Hasibuan (2007:122-123), adalah sebagai berikut :

\section{a. Asas Adil}

Besarnya kompensasi yang dibayar kepada setiap karyawan harus disesuaikan dengan prestasi kerja, jenis pekerjaan, resiko pekerjaan, tanggungjawab, jabatan pekerjaan dan memenuhi persyaratan internal konsistensi.

Jadi adil bukan berarti setiap karyawan menerima kompensasi yang sama besarnya. Asas adil harus menjadi dasar penilaian, perlakuan dan pemberian hadiah atau hukuman bagi setiap karyawan, dengan asas adil akan tercipta suasana kerjasama yang baik, semangat kerja, disiplin, loyalitas dan stabilitas karyawan akan lebih baik.

b. Asas Layak 
Kompensasi yang diterima karyawan dapat memenuhi kebutuhannya pada tingkat normatif yang ideal. Tolak ukur layak adalah relatif, penetapan besarnya kompensasi didasarkan atas batas upah minimal pemerintah dan eksternal konsistensi yang berlaku.

\section{Faktor-Faktor yang Mempengaruhi Kompensasi}

Faktor-faktor yang mempengaruhi kompensasi menurut Hasibuan (2007:127), yaitu :

1. Penawaran dan permintaan tenaga kerja

2. Kemampuan dan kesediaan perusahaan

3. Serikat buruh atau organisasi karyawan

4. Produktivitas kerja karyawan

5. Pemerintah dengan undang-undang dan keppresnya

6. Biaya hidup

7. Posisi jabatan karyawan

8. Pendidikan dan pengalaman karyawan

9. Kondisi perekonomian nasional

10. Jenis dan sifat pekerjaan.

Pendapat lain dikemukakan oleh Mangkunegara (2007:101), ada 6 (enam) faktor yang mempengaruhi kompensasi, yaitu :

1. Faktor pemerintah

2. Penawaran bersama

3. Standar dan biaya hidup pegawai

4. Ukuran perbandingan upah

5. Permintaan dan persediaan

6. Kemampuan membayar.

Menurut Herman Sofyandi dalam bukunya yang berjudul Manajemen Sumber Daya Manusia (2008, 162-163), faktor-faktor yang mempengaruhi kompensasi ada 8 faktor, yaitu sebagai berikut :

1. Adanya Permintaan dan Penawaran Tenaga Kerja

Permintaan tenaga kerja artinya pihak perusahaan sangat membutuhkan tenaga kerja, maka secara otomatis kompensasi relatif tinggi. Penawaran tenaga kerja artinya pihak individu yang membutuhkan pekerjaan, maka tingkat kompensasi relatif rendah.

2. Kemampuan dan Kesediaan Perusahaan Membayar

Bahwa ukuran besar kecilnya kompensasi yang akan diberikan kepada karyawan akan sangat tergantung kepada kemampuan financial yang dimiliki perusahaan, dan juga seberapa besar kesediaan dan kesanggupan perusahaan menentukan besarnya kompensasi untuk karyawannya.

3. Serikat Buruh atau Organisasi Karyawan

Pentingnya eksistensi karyawan dalam perusahaan, maka karyawan akan membentuk suatu ikatan dalam rangka proteksi atas kesemena-menaan pimpinan dalam menperdayakan karyawan, dalam hal ini muncul rasa yang menyatakan bahwa perusahaan tidak akan bisa mencapai tujuannya tanpa ada karyawan, dengan demikian maka akan mempengaruhi besarnya kompensasi.

4. Produktivitas Kerja/Prestasi Kerja Karyawan Kemampuan karyawan dalam menghasilkan prestasi kerja akan sangat mempengaruhi besarnya kompensasi yang akan diterima karyawan.

5. Biaya Hidup

Tingkat biaya hidup disuatu daerah akan menentukan besarnya kompensasi, sebagai contoh tingkat upah di daerah atau kota terpencil akan lebih kecil dibandingkan dengan tingkat upah di kota-kota besar.

6. Posisi atau Jabatan Karyawan

Tingkat jabatan yang dipegang karyawan akan menentukan besar-kecilnya kompensasi yang akan diterimanya, juga berat ringanya beban dan tanggungjawab suatu pekerjaan.

7. Tingkat Pendidikan dan Pengalaman Kerja

Pendidikan dan pengalaman berperan dalam menentukan besarnya kompensasi bagi karyawan. Semakin tinggi pendidikan karyawan dan semakin banyak pengalaman kerja, maka semakin tinggi pula kompensasinya.

8. Sektor Pemerintah

Pemerintah sebagai pelindung masyarakat berkewajiban untuk mentertibkan sistem kompensasi yang ditetapkan perusahaan/ organisasi, serta instansi-instansi lainnya, agar karyawan mendapat kompensasi yang adil dan layak, seperti dengan dikeluarkannya kebijakan pemerintah dalam hal pemberian upah minimum bagi para karyawan.

Dari beberapa pendapat diatas tentang faktor yang mempengaruhi besarnya kompensasi, dapat diambil kesimpulan bahwa dalam menentukan besarnya kompensasi pihak perusahaan mutlak perlu adanya manager professional yang benar-benar ahli dalam menentukan kompensasi, supaya dalam 
penentuan pemberian kompensasi bisa memberikan keuntungan bagi perusahaan dan karyawan.

\section{Bentuk Kompensasi Karyawan}

Kompensasi yang diberikan kepada karyawan ada dua bentuk yaitu bentuk langsung yang merupakan upah, gaji serta upah insentif dan bentuk kompensasi tidak langsung merupakan pelayanan dan keuntungan atau fringe benefit. Untuk hal tersebut secara singkat dapat diuraikan sebagai berikut :

1. Kompensasi Langsung

a. Gaji dan Upah

Menurut Hasibuan (2007:118), “Gaji adalah balas jasa yang dibayar secara periodik kepada karyawan serta mempunyai jaminan yang pasti, maksudnya gaji akan tetap dibayarkan walaupun pekerja tersebut tidak masuk kerja".

"Upah adalah balas jasa yang dibayarkan kepada pekerja harian dengan berpedoman atas perjanjian yang disepakati membayarnya".

Pendapat lain dikemukakan

oleh

Mangkunegara (2007 : 85) : Upah adalah pembayaran berupa uang untuk pelayanan kerja atau uang yang biasanya dibayarkan kepada karyawan secara per jam, per hari dan per setengah hari. Sedangkan gaji merupakan uang yang dibayarkan kepada karyawan atas jasa pelayanannya yang diberikan secara bulanan.

Panggabean (2009 : 77), mengemukakan bahwa : Gaji adalah imbalan financial yang dibayarkan kepada karyawan secara teratur, seperti tahunan, caturwulan, bulanan atau mingguan. Sedangkan upah adalah imbalan financial langsung yang dibayarkan kepada para pekerja berdasarkan jam kerja, jumlah barang yang dihasilkan atau banyaknya pelayanan yang diberikan.

Dari Pendapat diatas penulis menyimpulkan tentang upah dan gaji adalah gaji merupakan kompensasi langsung yang diberikan perusahaan kepada karyawan atas jasa-jasa yang telah diberikan karyawan kepada perusahaan dibayarkan secara periodik. Sedangkan upah adalah kompensasi langsung yang diberikan perusahaan kepada karyawan berdasarkan jam kerja, jumlah barang yang dihasilkan dengan berpedoman atas perjanjian yang disepakati bersama.

b. Insentif

Menurut pendapat Melayu S.P. Hasibuan (2007 : 118) :"Insentif adalah tambahan balas jasa yang diberikan kepada karyawan tertentu yang prestasinya diatas prestasi standar.

Mutiara S. Panggabean (2009: 77), mengemukakan bahwa :"Insentif merupakan imbalan langsung yang dibayarkan kepada karyawan karena kinerjanya melebihi standar yang ditentukan".

Pendapat lain dari Sarwono (2009 : 144), bahwa : Insentif adalah suatu sarana motivasi dapat diberikan batasan perangsang ataupun pendorong yang diberikan dengan sengaja kepada karyawan agar dalam diri mereka timbul semangat yang lebih besar untuk berprestasi bagi organisasi.

Dengan demikian insentif pada dasarnya merupakan daya pendorong untuk meningkatkan semangat kerja, yang pada gilirannya dapat meningkatkan prestasi kerja serta dapat meningkatkan prodiktivitas kerja, tentu saja upah insentif ini tidak akan sama bagi semua karyawan karena sistem insentif ini dibayarkan berdasarkan prestasi kerja karyawan.

2. Kompensasi Tidak Langsung

Bentuk kompensasi tidak langsung adalah pelayanan dan keuntungan atau Fringe Benefit yang diberikan kepada karyawan, dengan tujuan meningkatkan kesejahteraaan karyawan, meningkatkan moral kerja, dan meningkatkan keamanan kerja.

Menurut pendapat Hasibuan (2007 : 118) :

Kesejahteraan

pelengkap/fringe benefit adalah kompensasi tambahan (financial atau nonfinansial) yang diberikan berdasarkan kebijaksanaan perusahaan terhadap semua karyawan dalam usaha meningkatkan kesejahteraan mereka, seperti tunjangan hari raya, uang pensiun, pakaian dinas. Kafetaria, mushola, olahraga dan darmawisata.

Pendapat lain dikemukakan oleh A.A Anwar Prabu Mangkunegara (2007 : 86) : Benefit adalah nilai keuangan langsung untuk karyawan yang secara cepat dapat ditentukan. Sedangkan pelayanan adalah nilai keuangan langsung untuk pegawai yang tidak dapat secara mudah ditentukan.

Mutiara S. Panggabean (2009 : 77), mengemukakan bahwa : Fringe Benefit merupakan kompensasi tambahan yang diberikan berdasarkan kebijaksanaan perusahaan terhadap semua karyawan dalam usaha meningkatkan kesejahteraan para 
karyawan, contohnya asuransi jiwa dan bantuan perumahan.

Jadi kompensasi tidak langsung merupakan kompensasi tambahan yang diberikan perusahaan kepada semua karyawan berdasarkan kebijaksanaan perusahaan dalam usaha meninglkatkan kesejahteraan karyawan.

\section{Kerangka Pemikiran}

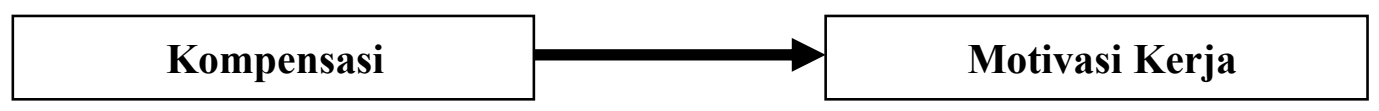

\section{Gambar 1. Kerangka Pemikiran}

\section{METODE PENELITIAN}

Metode yang digunakan dalam penelitian ini adalah analisis deskriptif. Menurut Nazir (2005:54) metode deskriptif adalah : Suatu metode dalam meneliti status sekelompok manusia, suatu objek, suatu set kondisi, suatu sistem pemikiran, ataupun suatu kelas peristiwa pada masa sekarang, dengan tujuan untuk membuat deskripsi, gambaran atau lukisan secara sistematis, factual dan akurat mengenai fakta-fakta, sifat-sifat serta hubungan antarfenomena yang diselidiki.

Ditinjau dari jenis masalah yang diselidiki, teknik dan alat yang digunakan, serta tempat dan waktu penelitian dilakukan, penelitian deskriptif yang digunakan dalam penelitian ini adalah metode verifikatif dengan pendekatan studi kasus. Penelitian verifikatif adalah penelitian yang bertujuan untuk menguji hubungan variabel dari hipotesis-hipotesis yang diajukan disertai data empiris. Penelitian verifikatif bertujuan untuk menguji kausalitas variabel-variabelnya. Adapun Maxfield (dalam Nazir, 2005:57).

\section{Populasi dan Sample Penelitian}

Populasi dalam penelitian ini adalah karyawan pada BPRS di kabupaten/kota Sukabumi yang berjumlah 136 orang. Teknik sampling yang digunakan adalah metode probability sampling, yaitu teknik pengambilan sampel yang memberikan peluang yang sama bagi setiap unsur atau anggota populasi untuk dipilih menjadi anggota sampel (Sugiyono, 2013 : 74). Adapun teknik probability sampling yang digunakan adalah teknik simple random sampling, yaitu pengambilan sampel populasi secara acak tanpa memperhatikan strata yang ada dalam populasi itu.

Penelitian ini tidak dilakukan pada seluruh individu dalam populasi, hal ini disebabkan jumlah populasi terlalu banyak, sehingga dalam penelitian ini jumlah sampel yang diperlukan dihitung dengan rumus dari Slovin, yang diambil dari buku Husein Umar (2001:78), yaitu sebagai berikut :

$$
\mathrm{n}=\frac{\mathrm{N}}{1+\mathrm{Ne}^{2}}
$$

Ket : $\mathrm{n}=$ Ukuran sampel; $\mathrm{N}=$ Jumlah populasi; $\mathrm{E}=$ Persentase kelonggaran ketidakpastian 15\%

$$
\mathrm{n}=\frac{136}{1+136(0.15)^{2}}=33.33
$$

Jadi ukuran sampel yang dipakai setelah dibulatkan adalah 33 orang.

\section{Konsep Variabel}

Dalam penelitian terdapat 2 variabel yang diteliti yaitu :

a. Kompensasi (X) "Adalah semua pendapatan yang berbentuk uang, barang langsung atau tidak langsung yang diterima karyawan sebagai imbalan atau jasa yang diberikan kepada perusahaan", Hasibuan (2007 : 118).

b. Motivasi Kerja (Y) "Didefinisikan sebagai kondisi yang berpengaruh, membangkitkan, mengarahkan dan memelihara perilaku yang berhubungan degan lingkungan kerja", (Mangkunegara, 2007 : 94).

\section{Uji Validitas}

Instrumen peneliti diuji coba dengan tujuan untuk mengetahui apakah instrumen telah memenuhi persyaratan ditinjau dari segi kesahihan/validitas maupun dari segi keterandalan/reliabilitas. Hasil 
penelitian yang valid, bila terjadi kesamaan antara data yang terkumpul dengan data yang sesungguhnya terjadi pada objek yang diteliti. Validitas (Kesahihan) berkaitan dengan instrumen tersebut dapat digunakan untuk mengukur apa yang seharusnya diukur.

Alat pengujian yang dipakai adalah Korelasi Product Moment, rumus dari Karl Pearson sebagaimana yang tertuang dalam Arikunto (2009 : 162), adalah sebagai berikut :

$$
\mathrm{r}_{\mathrm{xy}}=\frac{\mathrm{n} \cdot \Sigma \mathrm{XY}-(\Sigma \mathrm{X})(\Sigma \mathrm{Y})}{\sqrt{\left\{\mathrm{n} \Sigma \mathrm{X}^{2}-(\Sigma \mathrm{X})^{2}\right\}\left\{\mathrm{n} \Sigma \mathrm{Y}^{2}\right)-(\Sigma \mathrm{y})^{2}}}
$$

Dimana :

$\mathrm{r} \quad=$ Koefisien validitas butir pernyataan yang dicari

$\mathrm{n}=$ Banyaknya responden (di luar penelitian yang sebenarnya)

$\mathrm{X}=$ Skor yang diperoleh subjek dari seluruh item

$\mathrm{Y}=$ Skor total yang diperoleh dari seluruh item

$\Sigma \mathrm{X}=$ Jumlah skor dalam distribusi $\mathrm{X}$

$\Sigma \mathrm{Y} \quad=$ Jumlah skor dalam distribusi $\mathrm{Y}$

$\Sigma \mathrm{X}^{2}=$ Jumlah kuadrat masing-masing distribusi $\mathrm{X}$

$\Sigma \mathrm{Y}^{2}=$ Jumlah kuadrat masing-masing distribusi $\mathrm{Y}$

Untuk mengetahui signifikan atau tidak, maka harga $t_{\text {hitung }}$ tersebut perlu dibandingkan dengan harga $t_{\text {tabel }}$ dengan tingkat kesahihan

$5 \%$. Bila $t_{\text {hitung }}$ lebih besar dari $t_{\text {tabel }}$ maka signifikan sehingga instrumen dinyatakan valid.

\section{Uji Reliabilitas}

Reabilitas menunjuk pada pengertian bahwa sesuai instrumen cukup dipercaya untuk digunakan sebagai alat pengumpul data karena instrumen tersebut sudah baik. Instrumen yang baik tidak akan bersifat tendensius mengarahkan responden untuk memilih jawaban-jawaban tertentu. Hasil penelitian yang realibel, bila terdapat kesamaan data dalam waktu yang berbeda. Reliabilitas instrumen merupakan syarat untuk pengujian validitas instrumen.

Untuk mengukur reliabilitas kuesioner dalam penelitian ini digunakan Metode Alpha Cronbach dengan rumus :

$$
\mathrm{r}=\mathrm{k} \quad\left(\underline{\left(1-\Sigma \sigma \mathrm{i}^{2}\right)}\right.
$$

$$
\mathrm{k}-1 \quad \sigma^{2}
$$

Dimana :

$\mathrm{R}=$ Koefisien reliabilitas yang dicari

$\mathrm{K}=$ Jumlah butir pernyataan

$\Sigma \sigma \mathrm{i}^{2} \quad=$ Varians butir-butir pertanyaan (soal)

$\sigma^{2} \quad=$ Varians skor tes

\section{Teknik Analisa Data}

Teknik analisa data yang digunakan dalam penelitian ini adalah teknik analisis kuantitatif yang digunakan untuk mengukur sejauhmana pengaruh kompensasi terhadap motivasi kerja. Yaitu dengan menggunakan koefisien korelasi Rank Spearman seperti menurut Sidney Siegel (2002 : 256), adalah sebagai berikut :

\section{Koefesien Korelasi Rank Spearman \\ a) Jika tidak ada data kembar :}

$$
\mathrm{rs}=1-\frac{6 \Sigma \mathrm{di}^{2}}{\mathrm{~N}^{1}-\mathrm{N}}
$$

Dimana :

rs $\quad=$ Koefesien Korelasi Rank Spearman

$\Sigma \mathrm{di}^{2}=$ Selisih dari pasangan peringkat

$\mathrm{N} \quad=$ Banyaknya pasangan data

b) Jika ada data kembar :

$r s=-\frac{\Sigma \mathrm{X}^{2}+\Sigma \mathrm{Y}^{2}-\Sigma \mathrm{di}^{2}}{2 \sqrt{\Sigma \mathrm{X}^{2} \Sigma \mathrm{Y}^{2}}}$

Ket : $\quad \mathrm{rs}=$ Koefesien Rank Spearman ; $\Sigma \mathrm{X}^{2}=$ Jumlah nilai pengamatan item kuadrat $X$; $\Sigma \mathrm{Y}^{2}=$ Jumlah nilai pengamatan $\mathrm{Y} ; \quad \Sigma \mathrm{di}^{2}=$ Beda antara dua pengamatan berpasangan kuadrat

Sehingga :

$$
\begin{aligned}
& \Sigma \mathrm{X}^{2}=\frac{\mathrm{N}^{3}-\mathrm{N}}{12} \mathrm{Tx} \\
& \Sigma \mathrm{Y}^{2}=\frac{\mathrm{N}^{3}-\mathrm{N}}{12} \mathrm{Ty}
\end{aligned}
$$

Ket : $\Sigma X^{2}=$ Jumlah nilai pengamatan item kuadrat; $\Sigma Y^{2}=$ Jumlah nilai pengamatan total 
kuadrat; $\mathrm{N}=$ Banyaknya responden

c) Tx dan Ty Berturut-turut adalah banyaknya nilai pengamatan $\mathrm{X}$ dan pengamatan $\mathrm{Y}$ yang berangka sama untuk suatu peringkat sedangkan rumus untuk Tx dan Ty itu sendiri adalah sebagai berikut :

$$
\begin{aligned}
& \Sigma T \mathrm{x}=\frac{\mathrm{t}^{3}-\mathrm{t}}{12} \\
& \Sigma \mathrm{Ty}=\frac{\mathrm{t}^{3}-\mathrm{t}}{12}
\end{aligned}
$$

Ket : $\Sigma \mathrm{Tx}=$ Total skor item X; $\Sigma$ ty $=$ Total skor item $\mathrm{Y} ; \mathbf{t}=$ Banyaknya data kembar

\section{Uji Hipotesis Dengan Uji - t}

Untuk mengetahui keberartian nilai koefesien korelasi, maka pengujian hipotesis dapat dilakukan dengan menggunakan rumus menurut Sugiyono (2009 : 150), adalah sebagai berikut :

$$
\mathrm{t}=\mathrm{rs} \sqrt{\frac{\mathrm{N}-2}{1-\mathrm{rs}^{2}}}
$$

Ket : $\mathrm{t}=\mathrm{t}$ Hitung; $\mathrm{n}=$ Banyaknya responden; $\mathrm{r}_{\mathrm{s}}$ $=$ Koefesien korelasi

\section{Koefesien Determinasi}

Uji determinasi dilakukan untuk mengukur presentasi keluar variabel. Untuk mengetahui beberapa persen pengaruh kompensasi (variabel $\mathrm{X}$ ) terhadap motivasi kerja (Y) pada Shadiq Sharia ex BPRS Cipaganti Bandung, menurut Sugiyono (2013 : 150), dalam bukunya Metode Penelitian Bisnis dengan rumus sebagai berikut : $\mathrm{Kd}=\mathrm{rs}^{2} \mathrm{x} 100 \%$ Ket : $\mathrm{Kd}=$ Koefesien Determinasi; $r \mathrm{rs}=$ Koefesien Korelasi.

\section{Uji Validitas}

Instrumen penelitian diujicoba dengan tujuan untuk mengetahui apakah instrumen telah memenuhi persyaratan ditinjau dari segi kesahihan (validitas) maupun dari segi keterandalan (reliabilitas), seperti menurut Sugiyono (2009 : 109), mendefinisikan bahwa "valid berarti instrumen tersebut dapat digunakan untuk mengukur apa yang seharusnya diukur".

Maka dengan demikian, sebuah instrumen dikatakan sah apabila dapat mengukur apa yang seharusnya diukur. Selanjutnya, instrumen dikatakan valid apabila mampu mengukur apa yang diinginkan. Tinggi rendahnya validitas instrumen menunjukan sejauhmana data yang terkumpul tidak menyimpang dari gambaran tentang variabel yang dimaksud Arikunto (2009: 160).

Tabel 2. Tabulasi Korelasi Skor Item dengan Skor Total Instrumen pada Varibel $X$

\begin{tabular}{|c|c|c|c|}
\hline $\begin{array}{c}\text { No. Butir } \\
\text { Instrumen }\end{array}$ & $\begin{array}{c}\text { Koefisien } \\
\text { Korelasi }\end{array}$ & $\begin{array}{c}\text { Batas } \\
\text { Minimum }\end{array}$ & Keterangan \\
\hline 1 & 0.5906 & 0.514 & Valid \\
\hline 2 & 0.8155 & 0.514 & Valid \\
\hline 3 & 0.6916 & 0.514 & Valid \\
\hline 4 & 0.5518 & 0.514 & Valid \\
\hline 5 & 0.6852 & 0.514 & Valid \\
\hline 6 & 0.6165 & 0.514 & Valid \\
\hline 7 & 0.6653 & 0.514 & Valid \\
\hline 8 & 0.5824 & 0.514 & Valid \\
\hline 9 & 0.6901 & 0.514 & Valid \\
\hline 10 & 0.6916 & 0.514 & Valid \\
\hline 11 & 0.6934 & 0.514 & Valid \\
\hline 12 & 0.6675 & 0.514 & Valid \\
\hline 13 & 0.7389 & 0.514 & 0.514 \\
\hline 14 & 0.5994 & 0 & \\
\hline
\end{tabular}

Sumber : Data Kuesioner yang diolah 2015 
Berdasarkan hasil pengolahan data dengan validitas instrumen, diperoleh bahwa dari ke 14 item

pernyataan, dinyatakan valid.

Tabel 3. Tabulasi Korelasi Skor Item dengan Total Instrumen pada Variabel Y

\begin{tabular}{|c|c|c|c|}
\hline $\begin{array}{c}\text { No. Butir } \\
\text { Instrumen }\end{array}$ & $\begin{array}{c}\text { Koefisien } \\
\text { Korelasi }\end{array}$ & $\begin{array}{c}\text { Batas } \\
\text { Minimum }\end{array}$ & Keterangan \\
\hline 1 & 0.8039 & 0.514 & Valid \\
\hline 2 & 0.8309 & 0.514 & Valid \\
\hline 3 & 0.5474 & 0.514 & Valid \\
\hline 4 & 0.7099 & 0.514 & Valid \\
\hline 5 & 0.7281 & 0.514 & Valid \\
\hline 6 & 0.6916 & 0.514 & Valid \\
\hline 7 & 0.5474 & 0.514 & Valid \\
\hline 8 & 0.6934 & 0.514 & Valid \\
\hline 9 & 0.8155 & 0.514 & Valid \\
\hline 10 & 0.7099 & 0.514 & Valid \\
\hline 11 & 0.6852 & 0.514 & Valid \\
\hline 12 & 0.5474 & 0.514 & Valid \\
\hline 13 & 0.7281 & 0.514 & Valid \\
\hline
\end{tabular}

Sumber : Data Kuesioner yang diolah 2015

Berdasarkan hasil pengolahan data dengan validitas instrumen, diperoleh hasil bahwa dari ke 13 item pernyataan, semua item dinyatakan valid.

\section{Uji Reliabilitas}

Reliabilitas mencakup pada pengertian bahwa sesuatu instrumen cukup dipercaya untuk digunakan sebagai alat pengumpul data karena instrumen tersebut sudah baik. Instrumen yang baik tidak akan bersifat tendensius mengarahkan responden untuk memilih jawaban-jawaban tertentu.

Menurut Arikunto : Reliabilitas menunjuk pada tingkat keterandalan sesuatu reliable artinya terpercaya, dapat dipercaya, jadi dapat diandalkan (2009 : 170). Instrumen yang reliabel akan dapat menghasilkan data yang dapat dipercaya juga. Data yang sesuai dengan kenyataannya, maka berapa kalipun diambil, tetap akan sama.

\section{Tabel 4. Tabulasi Reliabilitas Berdasarkan} Rumus Alpha Cronbach Instrumen X dan Y

\begin{tabular}{|c|c|}
\hline Variabel & Alpha \\
\hline Kompensasi (X) & 0.8463 \\
\hline
\end{tabular}

\section{\begin{tabular}{|l|l|}
\hline Motivasi Kerja (Y) & 0.7361 \\
\hline
\end{tabular}}

Sumber : Hasil Pengolahan Data
Berdasarkan hasil perhitungan Alpha Cronbach tersebut di atas menunjukan variabel, reliabel. Karena menurut Burhan N. Gunawan Marzuki (2006:312) menyatakan bahwa seluruh variabel reliabel, bila harga indeks reliabilitas yang diperoleh paling tidak mencapai 0,6 sedangkan untuk tes - tes standar atau yang distandarkan, harga indeks reliabilitas paling tidak harus mencapai 0,85 atau bahkan 0,90 . Artinya berdasarkan data tersebut ratarata responden sungguh-sungguh dalam mengisi angket.

\section{Analisis Data}

Regresi sederhana didasarkan pada hubungan fungsional maupun kausal satu variabel independen dengan satu variabel dependen.

Peneliti melakukan pengolahan data regresi linier sederhana dengan menggunakan Program SPSS, diperoleh hasil : 
Tabel 5. Data Regresi Linier

\begin{tabular}{|c|c|c|c|c|c|}
\hline & \multicolumn{2}{|c|}{$\begin{array}{l}\text { Unstandarized } \\
\text { Coefficients }\end{array}$} & \multirow[t]{2}{*}{$\begin{array}{c}\begin{array}{c}\text { Standardi } \\
\text { Zed } \\
\text { Coefficien } \\
\text { ts }\end{array} \\
\text { Beta } \\
\end{array}$} & \multirow[b]{2}{*}{$\mathrm{t}$} & \multirow[b]{2}{*}{ Sig. } \\
\hline & B & Std. Error & & & \\
\hline $\begin{array}{ll}1 & \text { (Constant) } \\
\text { X }\end{array}$ & $\begin{array}{r}-1.175 \\
.385 \\
\end{array}$ & $\begin{array}{r}3.547 \\
.083\end{array}$ & .787 & $\begin{array}{l}-.331 \\
4.594 \\
\end{array}$ & $\begin{array}{l}.746 \\
.001\end{array}$ \\
\hline
\end{tabular}

a. Dependent Variable : Y

Berdasarkan hasil pengolahan data diperoleh Persamaan Regresi :

$\mathrm{Y}=-1,175+0,385 \mathrm{X}$

Artinya :

1) b bernilai positif yaitu 0,385 artinya terdapat pengaruh positif $\mathrm{X}$ terhadap $\mathrm{Y}$

2) Konstanta sebesar -1,175 menyatakan bahwa jika kompensasi tidak dipertimbangkan $(\mathrm{X}=0)$, maka motivasi kerja adalah sebesar $-1,175$ satuan, artinya motiasi kerja tidak tercapai.

3) Koefisien regresi sebesar 0,385 menyatakan bahwa setiap peningkatan (karena b bertanda +)1 satuan kompensasi akan meningkatkan motivasi kerja sebesar 0,385 satuan.

Contoh : Jika X (kompensasi) dilakukan minimal ( $\mathrm{X}=33$, maka $\mathrm{Y}$ (motivasi kerja) akan meningkat menjadi $\mathrm{Y}=-1,175+0,385(33=$ 11,92 satuan. Berarti dari hasil tersebut dapat dikatakan terdapat pengaruh positif $\mathrm{X}$ (kompensasi) terhadap Y (motivasi kerja), dan hipotesis kompensasi) teruji.

\section{Koefisien Korelasi Rank Spearman}

Penghitungan Koefisien korelasi antara X dan Y dicari dengan menggunakan rumus Korelasi Spearman, dimana alat analisis ini dipilih berdasarkan bentuk data yang akan diolah adalah berskala ordinal. Untuk itu, maka perlu dilakukan penyusunan data skor total jawaban responden pada setiap variabel menjadi urutan atau rangking (rank) sebagaimana rumus dasarnya dikemukakan oleh Siegel (2002 : 253) yang kemudian peneliti sesuaikan dengan notasi variabel.

Sebelum dapat menghitung besarnya koefisien korelasi Spearman, maka terlebih dahulu dicari nilai faktor koreksi (T), karena analisis data mentah menunjukan adanya data kembar. Rumus untuk menghitungnya adalah sebagai berikut :

$\Sigma \mathrm{Tx}=\frac{\mathrm{tx} 3-\mathrm{tx}}{12} \quad$ dan $\quad \Sigma \mathrm{Tx}=\frac{\mathrm{ty} 3-\mathrm{ty}}{12}$

Dimana :

$\mathrm{Tx}=$ Faktor korelasi yang dicari pada variabel X

Ty $=$ Faktor korelasi yang dicari pada variabel Y

ty/tx = Banyaknya observasi yang berangka sama setiap rangking

Dengan demikian, maka perhitungan koefisien korelasi Spearman antara X dan Y adalah sebagai berikut :

$$
\begin{aligned}
& \mathrm{rs}=\frac{\Sigma \mathrm{X} 2+\Sigma \mathrm{Y} 2-\Sigma \mathrm{Di} 2}{2 \sqrt{\Sigma \mathrm{X} 2 * \Sigma \mathrm{Y} 2}} \\
& \Sigma \mathrm{X} 2=\frac{\mathrm{N}^{3}-\mathrm{N}}{12}-\Sigma^{\mathrm{Tx}} \text { dan } \Sigma^{\mathrm{Y} 2}=\frac{\mathrm{N}^{3}-\mathrm{N}}{12}-\Sigma^{\mathrm{Ty}}
\end{aligned}
$$

Berdasarkan hasil perhitungan dengan menggunakan sebagai berikut : SPSS diperoleh hasil perhitungan koefisien korelasi 


\section{Tabel 6. Koefisien Korelasi}

Correlations

\begin{tabular}{|lrl|r|r|}
\hline & & $\mathrm{X}$ & \multicolumn{1}{|c|}{$\mathrm{Y}$} \\
\hline Spearman's rho & $\mathrm{X}$ & Correlation Coefficient & 1,000 & $.837^{\text {*** }}$ \\
& & Sig. (1-tailed) & $\cdot$ &, 005 \\
& $\mathrm{~N}$ & 33 & 33 \\
\cline { 2 - 4 } & $\mathrm{Y}$ & Correlation Coefficient &, $837^{* *}$ & 1,000 \\
& Sig. (1-tailed) &, 005 & $\cdot$ \\
& $\mathrm{N}$ & 33 & 33 \\
\hline
\end{tabular}

**. Correlation is significant at the .01 level ( 1 -tailed).

Jadi rs $=0,837$

\section{Koefisien Determinasi $\left(\mathbf{r s}^{2}\right)$}

Koefisien determinasi ini diperlukan untuk melihat beberapa besar pengaruh variabel $\mathrm{X}$ terhadap (Y). Perhitungannya diperoleh dengan cara mengkuadratkan koefisien korelasi.

Berdasarkan koefisien korelasi tersebut, maka hasil koefisien determinasi yang diperoleh adalah sebagai berikut :

$$
\mathrm{Kd}=\mathrm{rs}^{2} \mathrm{X} \quad 100 \%=0,837^{2} \mathrm{X} \quad 100 \%
$$$$
=70,06 \%
$$

Dengan demikian, maka kontribusi atau pengaruh kompensasi terhadap motivasi Kerja adalah sebesar 70,06\% atau dapat dikatakan pula, bahwa varians yang terjadi pada variabel Motivasi Kerja (Y) 70,06 \% ditentukan oleh varians yang terjadi pada variabel Kompensasi (X). Sisanya sebesar 29,94\% ditentukan oleh faktor-faktor lain diluar penelitian, seperti motivasi, upah, penempatan pegawai, dan lain-lain.

Berdasarkan hasil penelitian tersebut dapat digambarkan paradigma hasil penelitian sebagai berikut :

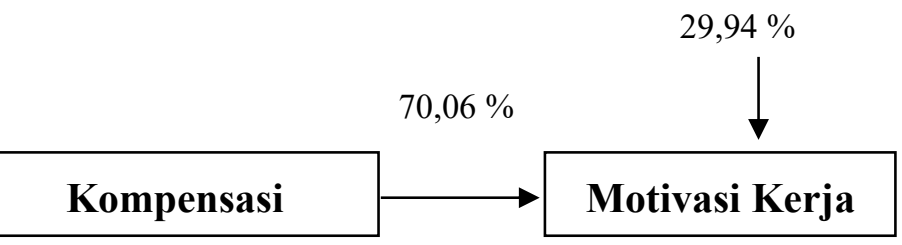

\section{Gambar 2. Paradigma Hasil Penelitian}

\section{Pembahasan Hasil Penelitian}

Kompensasi di PT. BPRS di kabupaten/kota Sukabumi

Bobot rata-rata variabel kompensasi (X) adalah sebesar 4,01 Bobot ini berada pada kategori tinggi, Artinya kompensasi yang diberikan perusahaan sudah tinggi tetapi masih belum optimal

\section{Motivasi di PT. BPRS di kabupaten/kota Sukabumi}

Bobot rata-rata variabel motivasi (Y) adalah sebesar 3,98 Bobot ini berada pada kategori tinggi, Artinya motivasi pegawai sudah tinggi tetapi masih belum optimal.

\section{SIMPULAN DAN SARAN}

Bahwa kompensasi yang diberikan PT. BPRS di kabupaten/kota Sukabumi sudah berjalan baik, hal ini terlihat dari tanggapan responden berdasarkan prosentase jawaban responden secara keseluruhan menyatakan puas atas pemberian bonus, gaji dan insentif yang sangat diperhatikan oleh pihak perusahaan.

Adapun kondisi motivasi kerja karyawan pada PT. BPRS di kabupaten/kota Sukabumi sudah dikatakan baik berdasarkan klarifikasi responden secara keseluruhan, sehingga karyawan merasa termotivasi untuk bekerja lebih giat lagi.

Dari analisis pengaruh kompensasi terhadap motivasi kerja pada PT. BPRS di kabupaten/kota Sukabumi, memiliki tingkat pengaruh yang sangat kuat sekali, hal ini berarti dengan semakin baiknya kompensasi yang diberikan oleh perusahaan, maka akan semakin baik pula motivasi kerja yang ditujukkan oleh para karyawan. Dengan adanya pengaruh kompensasi terhadap motivasi kerja diharapkan PT. BPRS di kabupaten/kota Sukabumi, akan dapat tumbuh dan terus berkembang dimasa depan.

Karyawan telah memberikan penilaian terbaik terhadap pelaksanaan pemberian kompensasi yang diberikan perusahaan namun berdasarkan hasil penelitian yang penulis lakukan masih ada beberapa 
hal yang perlu ditingkatkan lagi salah satunya dalam hal pemberian gaji, bila karyawan terpuaskan maka motivasi kerja karyawan akan lebih meningkat lagi.

Motivasi kerja karyawan pada PT. BPRS di kabupaten/kota Sukabumi dalam kondisi baik, maka perusahaan perlu mempertahankan dan meningkatkan motivasi kerja karyawannya.

Pengaruh kompensasi terhadap motivasi kerja pada PT. BPRS di kabupaten/kota Sukabumi menunjukan hasil yang positif, dengan adanya pengaruh tersebut penulis mengharapkan agar perusahaan dapat terus mengadakan perbaikan dan peningkatan terhadap pelaksanaan pemberian kompensasi yang sudah dijalankan oleh PT. BPRS di kabupaten/kota Sukabumi, untuk lebih memotivasi kerja para karyawannya.

\section{DAFTAR PUSTAKA}

Malayu, S.P. Hasibuan 2007. Manajemen Sumber Daya Manusia, cetakankesembilan, Jakarta : PT Bumi Aksara.

Herman Sofyandi.2008. Manajemen Sumber Daya Manusia.Graha Ilmu. Yogyakarta.

A.A. Anwar Prabu Mangkunegara, 2007, Manajemen Sumber Daya ManusiaPerusahaan, Bandung: PT. Remaja Rosdakarya.

Henry Simamora 2010 ,Manajemen Sumber Daya Manusia, Gramedia,Jakarta.

Mutiara S, Panggabean, (2005), Manajemen Sumber Daya Manusia, Bogor, Penerbit : Ghalia Indonesia.

Nazir, Moh. 2005. Metode Penelitian.Jakarta: Ghalia Indonesia.

Sugiyono. 2013. Metode Penelitian Pendidikan (Pendekatan Kuantitatif, Kualitatif, dan R\&D).Bandung : Alfabeta.

Husein Umar. (2001). Metode Penelitian dan Aplikasi dalam Pemasaran. Jakarta: PT Gramedia Pustaka Umum.

Siegel, Sidney, (2002), Metode Statistika NonParametris, Jakarta: Gramedia Pustaka Utama.

Arikunto, S., 2009. Prosedur Penelitian Suatu Pendekatan Praktik. Edisi Revisi 6. Jakarta : Rineka Cipta.

Burhan Nurgiantoro, Gunawan\& Marzuki.(2002), Statistik Terapan Untuk Penelitian Ilmu. Sosial.Yogyakarta: Gajah Mada University Press. 